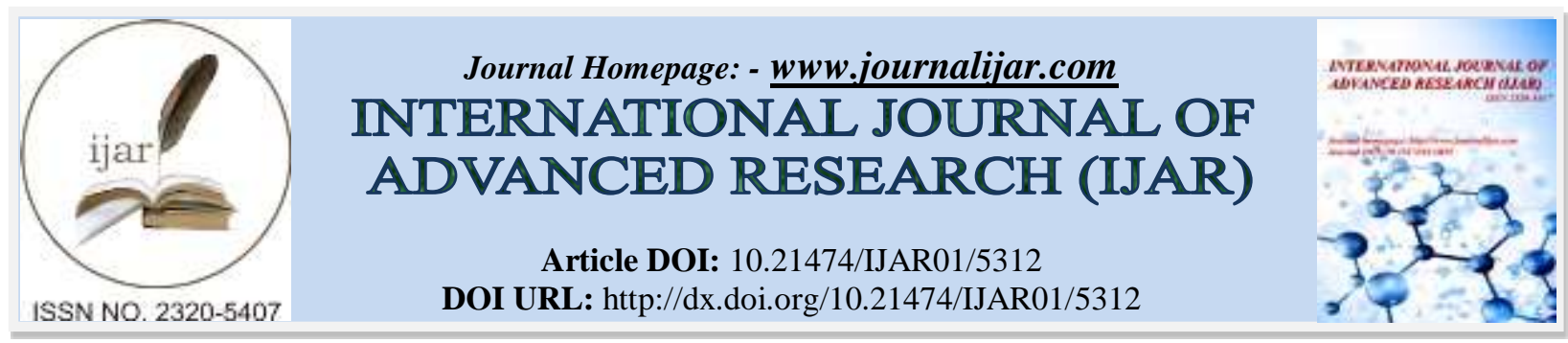

RESEARCH ARTICLE

\title{
IMPROVING THE QUALITY OF QUESTIONING SKILL PRACTICE ACHIEVEMENT IN MICROTEACHING BY APPLYINGCLINICAL SUPERVISION MODEL.
}

\author{
M. Sulthon Masyhud ${ }^{1}$, Zakiyah Tasnim ${ }^{2}$ and Khutobah ${ }^{3}$. \\ 1. Department of Elementary School Teacher Education,University of Jember, Indonesia. \\ 2. Department of English Language Education, University of Jember, Indonesia. \\ 3. Department of Early childhood Teacher Education, University of Jember Indonesia.
}

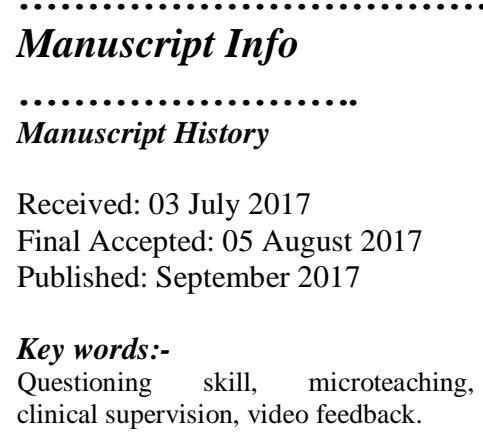

\begin{abstract}
This study aimed to find an effective way/ action to improve the quality of questioning skill practice achievement in Microteaching by using clinical supervision model. The research subjects were 15 students (prospective teachers) of elementary school teacher education program, who attended the microteaching class in the even semester of 2015/2016. The study was conducted in 2 cycles, by applying clinical supervision model with oral feedback and with video feedback. Performance test with observation checklist was used to collect the data needed. Statistics descriptive was applied to analyse the collected data.The research result showed that the application of clinical supervision model with video feedback can improve $23.90 \%$ of the quality of questioning skill practice achievement, reduce $69.26 \%$ of errors in asking questions, and increase $49,49 \%$ of the frequency of basic questioning skill practice
\end{abstract}

Copy Right, IJAR, 2017,. All rights reserved.

\section{Introduction:-}

Improving the quality of teaching and learning in schools requires professional teachers. The effort to have professional teachers has been done through the application of Competence Based Teacher Education (CBTE)curriculum. With the application of CBTE curriculum in Institution of Teacher Training Education (ITTE) is expected to be able to improve the performance of prospective teachers. Improving the performance of teacher candidates graduated from ITTE, is expected to be able to improve the quality of education graduates. Here CBTE is not just a means of achieving the competence of ITTE graduates, it is also as the achievement targets of the teacher candidates to achieve (Elam, 2001,General Directorate of Higher Education, 1998).

In relation to the above mentioned competencies, teaching has a very important role. Teaching competence is not only a formal demand that teachers must fulfill in order to graduate their education, but more than that, it is also the target as well as the benchmark for the success of their education as prospective teachers. The teaching competence here is a show of final ability to verify the success of their education before they are graduated from the ITTE. Teaching competence is an accumulation or combination between pedagogical competencies and subject matter competencies that have been trained during the professional teacher education process (General Directorate of Higher Education, 1998; Laughtin \& Moulto, 2012;Masyhud \& Zakiyah Tasnim, 16a).

Corresponding Author:- M. Sulthon Masyhud.

Address:- Department of Elementary School Teacher Education,University of Jember, Indonesia. 
Since the teaching competence has a very important role in the professional teacher education process, it needs to get more serious attention to produce professional teacher candidates. The competencies in the CBTE curiculum should be set beforehand, so that the competencies can be as a guide for every educational activity undertaken (Elam, 2011).

In CBTE, these competencies are achieved gradually through various activities, starting from: (1) theoretical activity, ie in the form of lecture activities on campus either related to the field of study to be taught, as well as related to pedagogical teories; (2) limited teaching practice activities, known as Microteaching activities, conducted on campus for preparing teaching practicum at school; and (3) teaching practicum at school under the guidance of a mentor from school and a supervisor from campus (Teaching Practicum and Microteaching Unit of Faculty of Teacher Training and Education, the University of Jember, 2010,General Directorate of Higher Education, 1998).

The three stages of the activities are given in sequence and can not be separated from one to another. The first stage, that is the theory activity, is the stage of understanding deeply about pedagogical theories and subject matter. In the second stage, the limited practice stage, or Microteaching is conducted on campus with friends as students. This stage focuses on training a variety of isolated teaching skills or integrated teaching skills in a limited time as well. These skills cover: 1) conducting set induction and closure, 2) delivering questions, 3) explaining learning materials, 4) giving stimulusand variation, 5) giving reinforcement, 7) teaching small groups and individuals, and 8) guiding small group discussions (Microteaching Lab, 1988). However, due to the wide range of skills and limited time for research activities, this classroom action research only focused on delivering questioning skills (Masyhud \& Zakiyah Tasnim, 2009; Brown, 2009; General Directorate of Higher Education, 2009; Tasnim \& M.Sulthon, 2017).

Questioning skill in teaching and learning activities, generally has a function to motivate students to learn well (Brown, 2000;Tasnim \& M.Sulthon, 2017 ). In more detail the skill has the following strengths: 1) to arouse students' interest and curiosity, 2) to focus students' attention to the lesson, 3) to diagnose students' learning difficulties, 4) to develop and activate students' learning method, 5) to provide opportunities for students to assimilate information, 6) to encourage students to express their views or opinions, and 7) to test or measure their learning outcomes (Masyhud \& Zakiyah Tasnim, 2009; Masyhud; Zakiyah Tasnim \& Misno, 2017; Microteaching Laboratory-Faculty of Teacher Training and Education, 2010).

Therefore, microteaching practice has a very important role. It is as a bridge between theory on campus and practice at a practicum school. In microteaching all the teaching skills are trained separately before they are practiced in an integrated way. By training separately it is expected that the training process can be observed carefully by the supervisor and can get input for improvement. With such separate practice, the prospective teachers will also be easier to master all the teaching skills well. If every teaching skill has been well mastered, then the prospective teacher will be easier to implement all the teaching skills integratedly in microteaching practice. Thus the microteaching practice results are expected to have a good impact on the results of teaching practice at the practicum school.

However, the fact showed that the result of micro-teaching practice of the students of Elementary School Teacher Education Program of Faculty of Teacher Training and Education of University of Jember had been less satisfactory. From the document at Teaching Practicum\& Microteaching Laboratory of Faculty of Teacher Training and Education the University of Jember during the last 5 semesters (starting from odd semester 2010/2011 to odd semester 2015/2016) indicated that the average score achieved by the Elementary School Teacher Education Program students was between 64.5 to 69.7. This showed that there was not optimal training and coaching process in microteaching practice. From the interview with 2 lecturers, it was found that at the beginning many students made similar mistakes in their microteaching practice. This indicated that the process of training and coaching in microteaching practice was still less effective. Therefore it is necessary to find an alternative model of ideal and effective coaching in microteaching practice, so that the results of microteaching practice can be optimum.

One model of ideal and effective couching in microteaching and teaching practice is by applying clinical supervision model (Acheson \& Gall, 2010; Krajewski, 2009; Masyhud \& Zakiyah Tasnim, 2009; General Directorate of Higher Education, 1999). The clinical supervision model is a model of democratic counseling, which emphasizes the initiative of the mentored candidate of teacher, places both the mentors and candidate of teachers as partner and equal, and there is no mentors'dominance (Krajewski 2009 ; Acheson, 2010; Masyhud \& Zakiyah Tasnim, 2009). The model also emphasizes on the use of recording formats or data recorder as a tool for observation on students' 
performance and giving immediate feedback, so that the feedback can be objective and the students still remember the fresh events have been done or experienced (Masyhud \& Zakiyah Tasnim, 2009, Masyhud, 1999).

The main focus of the couching process with this model of clinical supervision with video feedback is to improve teaching skills by means of systematic cycle in intensive planning, observation and analysis of real teaching performance, and aim to make changes logically (Masyhud \& Zakiyah Tasnim, 2009; Krajewski, 2009; ). As a model of a prospective teacher's approach, clinical supervision with video feedback has a goal to assist prospective teachers in minimizing the gap between real teaching behavior and expected ideal teaching behavior (Laoghtin, 2012; Masyhud \& Zakiyah Tasnim, 2009).

In addition, as a model for teacher candidates to improve their teaching skills, clinical supervision is considered ideal and effective. It is because the implementation of couching with the model of clinical supervision with video feedback takes place in a continuous process and refers to a comprehensive cycle of activities, which includes 3 stages of activity, namely: 1) the initial meeting stage, which is the stage of joined planning and contracting practise, 2) Observation, which observes the skills specified in the contract by using a negotiated instrument, and 3) the final meeting stage, which is the stage of giving feedback to the results of the practice and the determination of further steps of practice (Microteaching Laboratory Faculty of Teacher Training andEducation, The University of Jember, 2010; Krajewski, 2009; Masyhud \& Zakiyah Tasnim, 2009) ..

Therefore, by applying clinical supervision model in the Microteaching practice, it is expected that there will be an optimum improvement on the quality of the results of the questioning skills practice. Nevertheless, the extent to which the effectiveness of the clinical supervision with video feedback approach model for the improvement of questioning skill practice for the students of the Elementary School Teacher Education Program still needs to be investigated. Therefore this research was conducted

Based on the above description, this classroom action research problem can be formulated as follow: Is the application of clinical supervision model in Microteaching practice can improve the quality of the result of questioning skills training of the students of Elementary School Teacher Program of Faculty of Teacher Training and Education the University of Jember. To solve the research problem, an action research hypothesis was formulated as the guide for the action as the following: The application of the clinical supervision with video feedback model in Microteaching practice can improve the quality of the result of questioning skills training of the students of Elementary school program of Faculty of Teacher Training and Education, the University of Jember. The main expected significance of the results of this study was to obtain an ideal and effective model of coaching for the practice of questioning skills in Microteaching. By obtaining an ideal and effective model of coaching for the practise, it is expected that the quality of Microteaching practice result of the students of Elementary School Teacher Education Program could be improved.

\section{Research Methods:-}

This research applied classroom action research design with"participant-researcher model". The researcher was also investigated in this research. The research was done collaboratively between the lecturers of microteaching and educational technology and research experts. The work procedure of DDAER (Dialogue, Decision, Action, Evaluation and Reflection) (Elliot, 1991; Masyhud \& Zakiyah Tasnim, 2016b) was used in this research.

The location of the research was the campus of Faculty of Teacher Training and Education, the University of Jember, especially in Microteaching laboratory. The subjects of research were 15 students (prospective teachers) of Microteaching course from the Elementary School Teacher Program of Faculty of Teacher Training and Education, the University of Jember. Purposive area sampling method was used to decide the research subjects. The data collection method used in this research was assessment instrumnt for basic questioning skill. The procedures of this classroom action research consisted of the following: 1) diagnostic stage, 2) therapeutic stage, 3) re-diagnostic stage, and 4) re-therapeutic stage. The diagnostic stage covered identifying problem, collecting supporting data, formulating problem, analysing problem, and formulating action hypothesis (Eliot, 2011). To support this stage of activities, the following activities were carried out: 1) preliminary survey. This activity was intended as the introduction of field and/or sample research, 2) in-depth discussion with lecturers/ supervisors Elementary school program of Faculty of Teacher Training and Education the University of Jember. The discussion was intended to find problems by supervisors in guiding microteaching practice, obstacles in supervising the students while doing microteaching practice, and feedback about the implementation of microteaching activities that have been given. 
The next stage was therapeutic stage. At this stage the following activities were carried out: 1) planning of the actions. Planning was done collaboratively with the team members. 2) caring out the action. It was done by applying clinical supervision in the process of microteaching practice supervison based on the instructional planning has been done .3) conducting monitoring and evaluation. It was done to determine the impact of the actions to improve the prospective teachers' questioning skill. This activity was done by using assessment instrument formats; 4) reflecting. It was done to think deeply about the results of observation and assessment of the action, whether there was still problems that need attention so that re-action needs to be done. Re-diagnostic stage and re-therapeutic stage were only done if the results of the action in cycle I has not been satisfactory. There were two kinds of analysis models used: (1) descriptive-qualitative analysis, and (2) statistical-descriptive analysis (Masyhud, 2015; Ferguson, 1999; Kerlinger, 2006; Tuckman, 2008).

\section{Results and Discussion:-}

This classroom action research with two cycles showed the following results. In Cycle I the action provided training on basic teaching skill to the student about questioning skill by applying clinical supervision model with verbal feedback based on the records of microteaching practice results. In this cycle, the students were given suggestions orally. After finishing doing questioning skill practice in the first time in cycle 1 , then it was continued to practice the questioning skill again. The students'second training performance in cycle I was then directly assessed by the supervisor by using the assessment instrument that has been prepared by Microteaching Laboratory. The results of the assessment of the second practice in cycle I were then documented as data entry for the action in cycle 1.

After the first cycle was done, the students were then given an action by applying clinical supervision model with video feedback. It was done by referring to the supervision model which included: initial meeting, observation and video feedback on practice results. After being given clinical supervision by video, the teacher candidate were required to practice once again on questioning skills. Then, it was assessed to know whether or not there was an impact on applying clinical supervision model with video feedback. The microteaching practice on questioning skill after having clinical supervision with video feedback was also assessed using the same instrument as the one used in the first cycle. The results of the assessment of this cycle were then also documented as the entry data of the action in cycle 2. The data were compared with the results of the practice in cycle 1. The results of data comparison between cycle 1 and cycle 2 was then determined whether the action of cycle 2, that was the application of clinical supervision model with video feedback was effective or not. If it was effective then the relative effectiveness level shown by the action in cycle 2 would be calculated.

Based on the data analysis, it could be reported that all research subjects got a fairly high score improvement in Cycle 2 compared to their scores achieved in Cycle 1. The increase at least 8 points, was achieved by 1 student ( $6.67 \%$ ); While the highest increase, 22 points, was also achieved by 1 student (6.67\%). The total score of increase reached 218 points with an average increase of 14.53 points. The detail results can be seen in table 1 as follow.

Table 1:- The Comparison Between the Students' Scores of Questioning Skill Practice in Cycle1 and in Cycle 2

\begin{tabular}{|l|l|l|l|}
\hline \multirow{2}{*}{$\begin{array}{l}\text { Number ofthe } \\
\text { Reseach Subjects }\end{array}$} & \multicolumn{2}{|l|}{ The Score of Questioning Skill Practice } \\
\cline { 2 - 4 } 1. & Cycle 1 & Cycle 2 & Points of Increase \\
2. & 67 & 79 & 12 \\
3. & 68 & 81 & 13 \\
4. & 66 & 78 & 12 \\
5. & 64 & 81 & 17 \\
6. & 67 & 78 & 15 \\
7. & 61 & 84 & 17 \\
8. & 71 & 79 & 13 \\
9. & 62 & 78 & 17 \\
10. & 65 & 84 & 13 \\
11. & 68 & 82 & 16 \\
12. & 70 & 81 & 12 \\
13 & 73 & 83 & 08 \\
14 & 66 & 96 & 17 \\
15. & 72 & 88 & 20 \\
\hline
\end{tabular}




\begin{tabular}{|l|l|l|l|}
\hline Total score & 1016 & 1234 & 218 \\
\hline The average score & 66.40 & 82.27 & 14.53 \\
\hline
\end{tabular}

The comparison between the students' scores of questioning skill practice in Cycle 1 and in Cycle 2 is presented in the form of diagrams, it can be seen as the following.

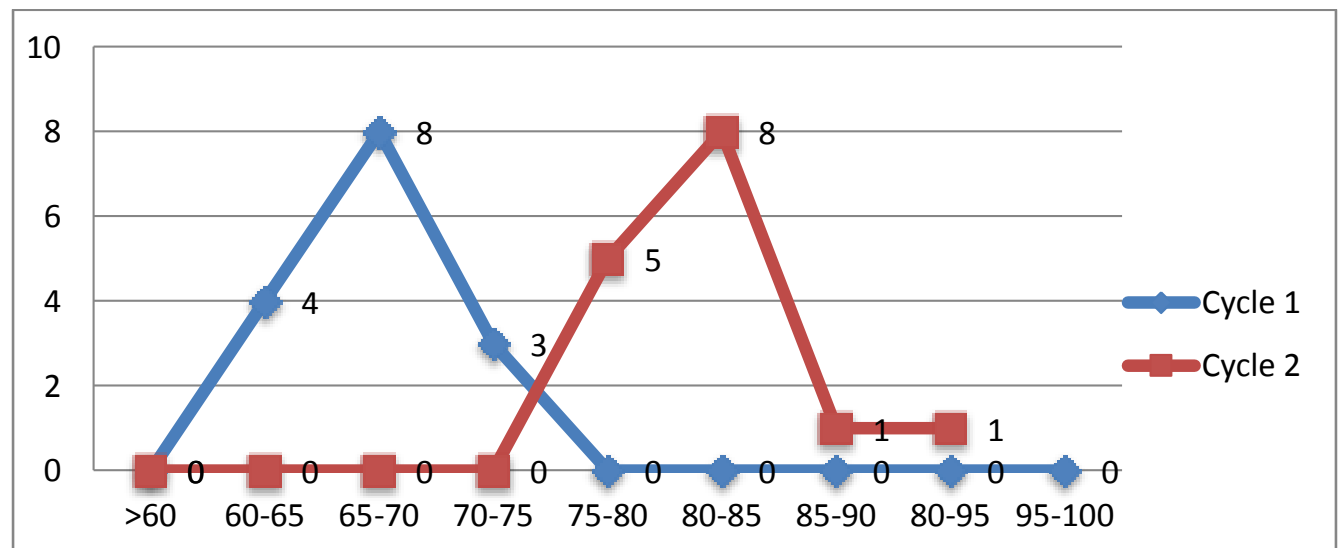

Diagram 1:- The Comparison Between the Students' Scores of Questioning Skill Practice in Cycle1 and in Cycle2

Based on the recording and data analysis in cycle 1 above, it can be understood that the highest score achieved by the students in basic questioning skill practice by applying clinical supervision with verbal feedback was 73; While the lowest score reached 61. The total score, from 15 students as the subjects of the study was 1016 and the average score was 67.07. While in Cycle 2 by applying clinical supervision model with video showed that all the research subjects' scores increased. The highest score in cycle 2 was 96 and the lowest score was 78 . The total score for 15 students in Cycle 2 was 1234 with an average score of 82.27.

The improvement of those scores can also be used as the indicator of the effectiveness level of the actions by applying clinical supervision model with feedback from video recording the basic questioning skill practice of the students of Elementary School Teacher Education program. From the comparison of the scores in cycle 1 and cycle 2 above, it was found that the action in cycle 2, that was applying clinical supervision model with feedback from video, was more effective in improving the students' basic questioning skill practice achievement compared to applying clinical supervision model with verbal feedback.

The complete comparison between the effectiveness of applying clinical supervision model with video feedback and applying clinical supervision model with verbal feedback to improve the students' questioning skill practice in cycle 1 and in cycle 2 can be seen as the following.

Table 2:- The Comparison of the Effectiveness of the Action in Cycle 1: Applying Clinical Supervision Model with verbal feedback and the Action in Cycle 2: Applying Clinical Supervision Model with Video feedback

\begin{tabular}{|l|l|l|l|l|l|l|l|}
\hline Cycle & N & Max & Min & Total & Mean & Range & SD \\
\hline 1 & 15 & 73 & 61 & 1016 & 66,40 & 12 & 3,32 \\
\hline 2 & 15 & 96 & 78 & 1234 & 82,27 & 8 & 4,54 \\
\hline
\end{tabular}

Based on the data recording in tables 1 and 2 above it can be seen that the action in Cycle 2 had a relative effectiveness level of $23.90 \%$ compared to the action in cycle 1 . In other words the action in Cycle 2 was more effective $23.90 \%$ compared to the action in Cycle 1. This means that if in cycle 1 the average score achieved by the group was 50, then in cycle 2 their average score increased to be 61.95. The increase was sifgnificant because the results of the t-test analysis was 12.78 which was greater than the value of t-table ( 4.15 ). The increase of achievement in Cycle 2 happened to all students. There was no student in Cycle 2 whose achievement was not increased compared to cycle 1 . The achievement improvement was between 8 to 22 points.

When the achievement of questioning skill practice in cycle 1 and cycle 2 was compared by using scale of 5 , that was Very Good, Good, Fair, Bad and Very Bad can be seen in table 3 as follows. 
Table 3:- The Comparison Between Questioning Skill Practice Achievement in Cycle 1 and in Cycle 2 Based on 5 Rating Classification

\begin{tabular}{|l|l|l|l|l|l|}
\hline No & Value Category & Cycle1 & \multicolumn{2}{l|}{ Cycle2 } \\
\cline { 3 - 6 } & & F & $\%$ & F & $\%$ \\
\hline 1. & Very good & 0 & 0,00 & 10 & 66,67 \\
\hline 2. & Good & 4 & 26,67 & 5 & 33,33 \\
\hline 3. & Fair & 9 & 60,00 & 0 & 0,00 \\
\hline 4. & Bad & 2 & 13,33 & 0 & 0,00 \\
\hline 5. & Very Bad & 0 & 0,00 & 0 & 0,00 \\
\hline TOTAL & 15 & 100 & 15 & 100 \\
\hline
\end{tabular}

Based on the above comparison table, it can be seen that in cycle 1, with the action of applyingg clinical supervision model with verbal feedback, the students' scores ranged from bad category to good category, although most of them $(60 \%)$ were in enough category. While in cycle 2 , in which the action of applying clinical supervision model with video recording feedback, the students' scores were in good category and very good category, with relative frequencies of $33,33 \%$ and $66,67 \%$ respectively.

Other findings were related to any habits that teachers should avoid in applying basic questioning skills while conducting an instruction. Of the 6 types of the habits, in Cycle 1, almost all of those habits were performed by teacher candidates with frequencies ranging from $20 \%$ to $60 \%$ for each type of habit that should be avoided. While in Cycle 2, the violation of habits that should be avoided decreased dramatically, ie between $0 \%$ to $25.67 \%$ on each type of habit that should be avoided. In detail, the data can be seen in table 4 as follow.

Table 4:- The Comparison Between Wrong Habit Types Which Students Do in the Application of Basic Questioning Skill Components in Cycle1 and in Cycle2, And the Error Reduction Levels in Post Clinical Supervision

\begin{tabular}{|l|l|l|l|l|l|l|}
\hline No & Types of Error in asking questions & \multicolumn{2}{l|}{ Cycle1 } & \multicolumn{2}{l|}{ Cycle2 } & \multirow{2}{*}{ Error Reduction Level } \\
\cline { 3 - 6 } & & F & $\%$ & F & $\%$ & \\
\hline 1. & Repeating his own question(ROQ) & 3 & 20,00 & 0 & 0,00 & $100 \%$ \\
\hline 2. & Repeat students' answers (RSA) & 6 & 40,00 & 2 & 13,33 & $66,68 \%$ \\
\hline 3. & $\begin{array}{l}\text { Answering his own question } \\
\text { (AOQ) }\end{array}$ & 3 & 20,00 & 1 & 6,67 & $66,65 \%$ \\
\hline 4. & $\begin{array}{l}\text { Question of simultaneous response } \\
\text { QSR) }\end{array}$ & 9 & 60,00 & 4 & 26,67 & $55,55 \%$ \\
\hline 5. & Double Question (DQ) & 9 & 60,00 & 3 & 20,00 & $66,67 \%$ \\
\hline 6. & $\begin{array}{l}\text { Determine the student first before } \\
\text { asking (DSFBA) }\end{array}$ & 5 & 33,33 & 2 & 13,33 & $60,01 \%$ \\
\hline Average errorreductionlevel & & & & $\mathbf{6 9 , 2 6 \%}$ \\
\hline
\end{tabular}

From the data analysis results in table 4 it can be seen, that in cycle 2, the act of providing guidance by using the model of clinical supervision with video feedback can reduce the wrong habits in applying questioning skill between $55.55 \%$ to $100 \%$ per type of wrong habit to be avoided. When averaged all the components of the wrong habits, it was found the wrong errors are quite high, that was equal to $69.26 \%$. This means that the process of supervising with a clanical supervision model with video feedback was also effective in reducing the wrong habit of appying basic questioning skill. It was done in one additional cycle. If the cycle was added again, it could be predicted that the reduction would increase more.

Error levels of reduction of the use of wrong habits can be read in the following diagram. 


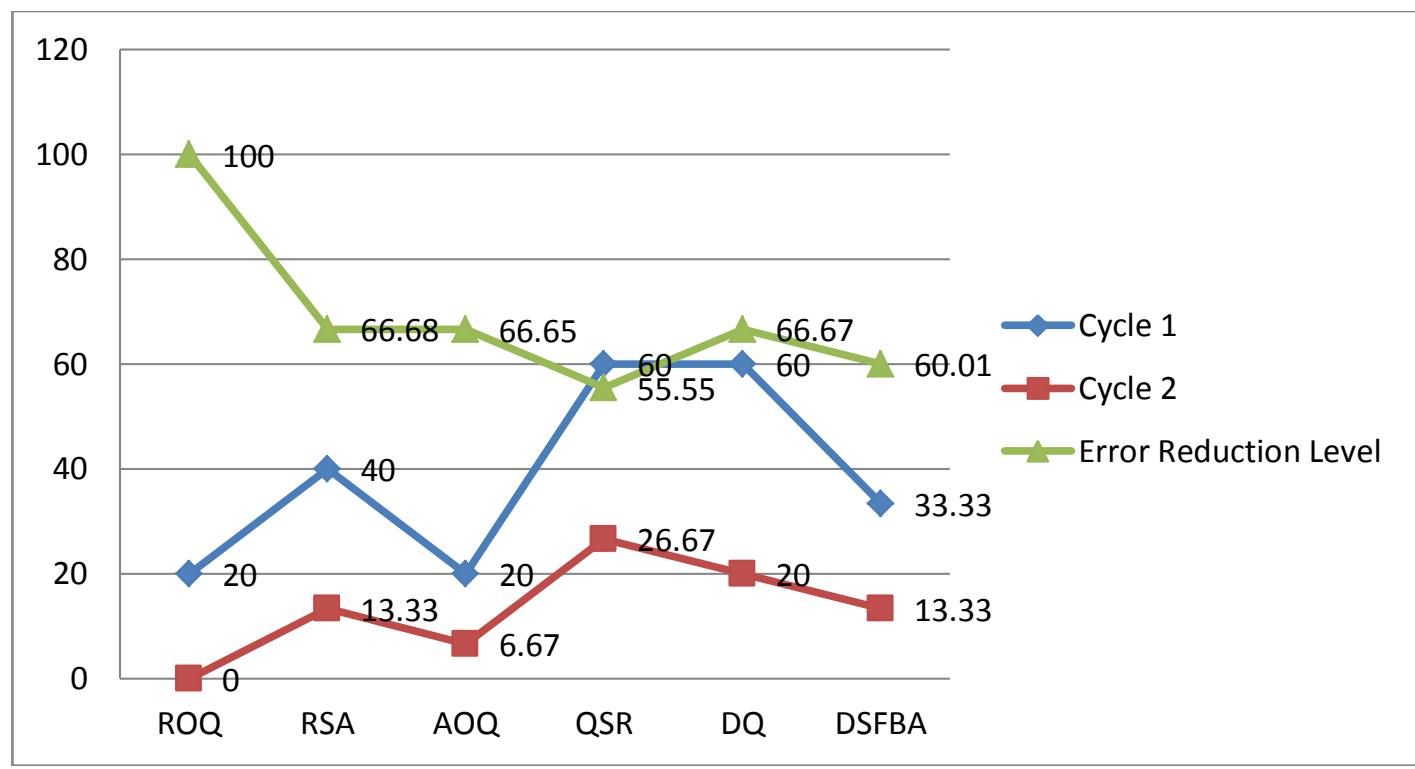

Diagram 2:- Types of Wrong Habit In Applying Questioning Skill In Cycle 1 and Cycle 2 And the Level Of Reduction Post Couching of Clinical Supervision

In addition, in cycle 2 of this classroom action research there were 3 (20.00\%) research subjects who performed the same repeated error as the one done in Cycle 1. Repetition of the errors was related to: 1) asking double questions done by one teacher candidate, and 2) using questions causing students to answer altogether, conducted by 2 propective teachers. Futhermore,there were other errors occured in cycle 1 only, but they did not in cycle 2 . For example, error in repeating student's answers and repeating their own answers. Those errors occured 29 times and done by 7 students (46.67\%). In addition there were also types of errors that occurred in cycle 2 only, but not in cycle 1 . This error occured 6 times $(50 \%)$ of the total errors $(12$ times) in the 2 nd cycle. The errors were done by 4 prospective teachers.

Concerning the application of basic questioning skill components in microteaching practice in this research, in general, the achievement was good. Of the 7 components of the basic questioning skill that should be applied by the prospective teacher in practice, it was known that prompting question was the most component left by the prospective teacher.This component was only performed by $6(40.00 \%)$ prospective teacher. However, redirecting component was performed by almost all prospective teachers $(93.33 \%)$, and there was only one prospective teacher did not do it. All the finding dealing with the application of basic questioning skill components can be seen in table 5 as the following.

Table 5:- The Application of Basic Questioning skill Components in Microteaching Practice by ProspectiveTeachers in Cycle 1 and Cycle 2 and The Level of Increase

\begin{tabular}{|l|l|l|l|l|l|l|}
\hline \multirow{2}{*}{ No } & Components of Basic Questioning Skills & \multicolumn{2}{l|}{ Cycle 1 } & \multicolumn{2}{l|}{ Cycle 2 } & \multirow{2}{*}{ Level of Increase } \\
\cline { 3 - 6 } & & F & $\%$ & F & $\%$ & \\
\hline 1. & Stating Questions Clearly (SQC) & 6 & 40,00 & 13 & 86,67 & $46,67 \%$ \\
\hline 2. & Giving reference (GR) & 1 & 6,67 & 11 & 73,33 & $66,66 \%$ \\
\hline 3. & FocusingQuestions (FQ) & 1 & 6,67 & 9 & 60,00 & $53,33 \%$ \\
\hline 4. & Re-directing Questions (RQ) & 9 & 60,00 & 14 & 93,33 & $33,33 \%$ \\
\hline 5. & Distributing QuestionsEvenly (DQE) & 6 & 40,00 & 13 & 86,67 & $46,47 \%$ \\
\hline 6. & Giving Timeto Think (GTT) & 3 & 20,00 & 12 & 80,00 & $60,00 \%$ \\
\hline 7. & Giving Prompt (GP) & 0 & 0,00 & 6 & 40,00 & $40,00 \%$ \\
\hline
\end{tabular}

More clearly, the comparison of each basic questioning skill component performed in the microteaching practice in cycle 1 and cycle 2 can be seen in diagram 3 as follows. 


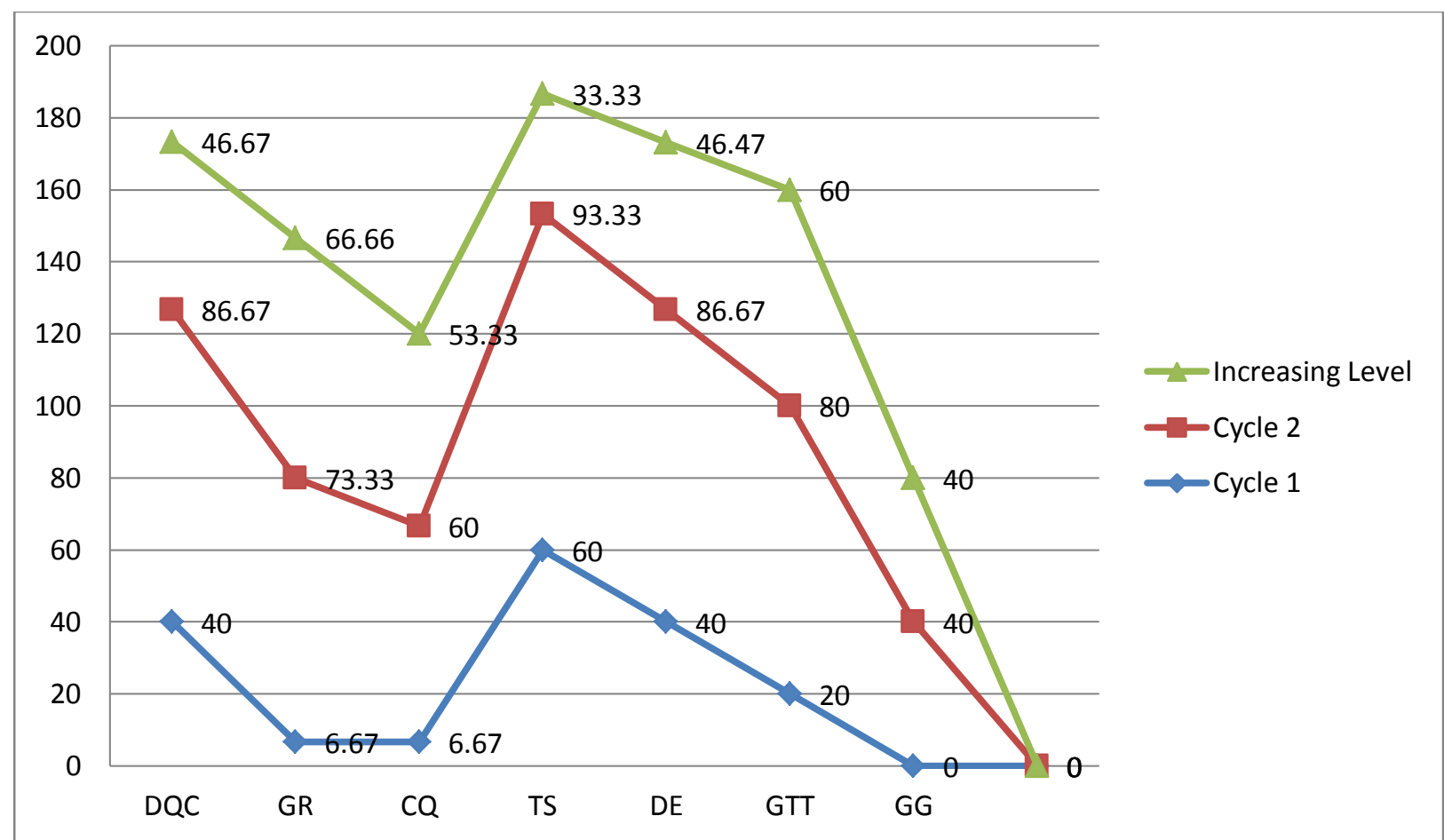

Diagram 3:- The Comparison of Each Basic Questioning Skill Component Performed in Microteaching Practice in cycle 1 and in cycle 2

Based on the results of the data analysis shown on table 5 and on diagram 3, it was found that the highest increase in the application of the basic questioning skill component in cycle 2 was on the component of giving time to think, that was $60 \%$; while the lowest increase was on redirecting component, that was $33.33 \%$. However, this component, redirecting component, had the highhest rank, ie $93.33 \%$ in cycle 2 .This happened, because this component showed a high enough frequency of occurrence, ie $60 \%$, in cycle 1.Thus, although in cycle 2 redirecting only showed an increase of $33.33 \%$, the overall effectiveness level was still high compared with the other components.

Furthermore, dealing with the average increase in the frequency of application of basic questioning skill components in microteaching practice in cycle 2 , this showed quite large, that was $49.49 \%$. This means that the application of clinical supervision model with video feedback was effective enough to increase the frequency of the application of questioning basic skill components. The increase in the frequency of application of basic questioning skills was 49. $49 \%$ achieved by adding 1 action cycle only. If the cycle of action was added, it was expected that the frequency of application of the basic questioning skill increased more. Therefore a further action research was still needed again to get an ideal supervision model on microteaching practice.

\section{Conclusion and Suggestion:-}

\section{Conclusion}

Based on the results of data analysis and discussion as presented in the previous section it could be concluded that, in general, clinical supervision model with video feedback could improve the quality of basic questioning skills practice achievement in microteaching practice. More specifically, the clinical supervision with video feedback model was able to: 1) improve the relative effectiveness of the quality of basic questioning skill practice achievement in about $23.90 \%$, 2) reduce the negative habits in the application of basic questioning skill components in about $69.26 \%$, and 3 ) increase the frequency of applying the basic questioning skill components in about $49.49 \%$.

\section{Suggestion}

Based on the results of the research the following points are suggested.The lecturers of Microteaching subjects, especially at the Faculty of Teacher Training and Education, the University of Jember, are suggested to apply clinical supervision with video feedback model to guide the prospective teachers to increase their quality achievement on practising basic questioning skill in microteaching practice. In addition, since the results of the 
study indicated that the clinical supervision with video feedback model is effective to improve the quality of the achievement of questioning skill practice, it is advisable to apply the clinical supervision with video feedback model in guiding the prospective teacher to practice other basic teaching skills, such as giving reinforcement skill and classroom management skill, etc, in microteaching practice.

\section{References:-}

1. Acheson, Keith A \& Meridith D Gall, 2010. Technques in The Clinical Supervision of Teacher, Preservice and Inservice Application. New York : Logman, Inc.

2. Brown, George, 2009. Microteaching A Programme of Teaching Skills. London : Methuen.

3. Elam, S., 2011. Performance-Based teacher Education : What is the State of The Art? Washington DC.: American Association of College For Teacher Education.

4. Elliot, John, 2011. Action Research for Educational Change. Milton Keynes, Philadelphia : Open University Press.

5. Ferguson, George, A., 1999. Staistical Analysis in Psychology and Education. New York : McGraw-Hill Book Company.

6. General Directorate of Higher Education, 1998. Developmental educational Project Book II : The Implementation of Teaching Practicum Jakarta : General Directorate of Higher Education

7. General Directorate of Higher Education, 2009. Microteaching. Jakarta : General Directorate of Higher Education; Higher education Development Project.

8. General Directorate of Higher Education,1999. Clinical Supervision. Jakarta: General Directorate of Higher Education; Higher education Development Project.

9. Kerlinger, Fred, N., 2006. Foundation of Behavioral research. New York : Holt, Rinehart and Winston, Inc.

10. Krajewski, Robert J., 2009. Cinical Supervision : A Conceptual Framework; In Journal of Research and Development in Edocation; Vo.15; No.2; pp 38 - 43.

11. Laughlin \& J. Moulton, 2012. Evaluation of Performance Training Methods : A Manual of Teaching Trainer. New York : UNESCO.

12. Masyhud, M. Sulthon dan Zakiyah Tasnim, 2009. Microteaching Management. Yogyakarta: Laksbang Pressindo.

13. Masyhud, M. Sulthon, 1999. The Correlation between Teacher Candidates' Expectation for being Teacher and TheirTeaching Practicum Achievement penelitian. Jember : Central of Research-The Univesity of Jember.

14. Masyhud, M. Sulthon, 2015. Statistical Data Analysis for Educational Research.Jember: The Institution of Management and Educational Profession Development.

15. Masyhud, M.Sulthon; ZakiyahTasnim, 2016a. Management of Educational Profession. Yogyakarta: The Gift of the Universe.

16. Masyhud, M. Sulthon; ZakiyahTasnim, 2016b. Educational Research Method for Teacher Candidate and Educational Practicant: Theory and Practice. Jember: The Institution of Management and Educational Profession Developmnet.

17. Masyhud, M. Sulthon; Zakiyah Tasnim; Misno A. Lathif, 2017. The Contribution of Grade Point Average (GPA), Microteching Practice Achievement and Motivation to be a Teacher on the Students' Teaching Practicum Achievement; International Journal of Research in Humanities and Social Studies, Volume 4, Issue 4, 2017, PP 22-27. India: Sryahwa Publications.

18. Microteaching Laboratory Faculty of Teacher Training and Education -The University of Jember, 2010. The Guide Line of Microteaching Implementation for the Students of Faculty of Teacher Training and Education. Jember: Microteaching Laboratory Faculty of Teacher Training and Education -The University of Jember.

19. Tasnim, Zakiyah \& M. Sulthon Masyhud, 2017. Improving the Students' Practice Achievement Quality of Giving Explanation Skill in Teaching Practicum by Using Clinical Supervision Model, The International Journal of Social Sciences and Humanities Invention 4(6): 3537-3540, 2017. India: THEIJSSHI

20. Tuckman, Bruce, W., 2008. Conducting Educational Research. New York : Harcourt Base Javanovich, Inc. 